

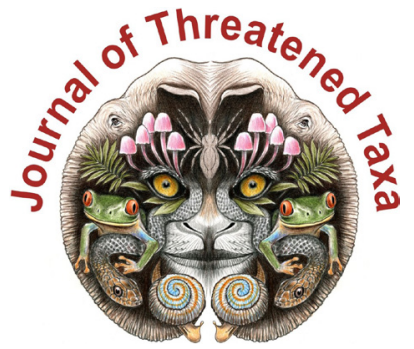

ISSN 0974-7907 (Online); ISSN $0974-7893$ (Print)

Publisher

Host

Wildlife Information Liaison Development Society

www.wild.zooreach.org

Zoo Outreach Organization www.zooreach.org

No. 12, Thiruvannamalai Nagar, Saravanampatti - Kalapatti Road, Saravanampatti, Coimbatore, Tamil Nadu 641035, India

Ph: +91 9385339863 | www.threatenedtaxa.org

Email: sanjay@threatenedtaxa.org

EDITORS

\section{Founder \& Chief Editor}

Dr. Sanjay Molur

Wildlife Information Liaison Development (WILD) Society \& Zoo Outreach Organization (ZOO),

12 Thiruvannamalai Nagar, Saravanampatti, Coimbatore, Tamil Nadu 641035, India

\section{Deputy Chief Editor}

Dr. Neelesh Dahanukar

Noida, Uttar Pradesh, India

\section{Managing Editor}

Mr. B. Ravichandran, WILD/ZOO, Coimbatore, India

\section{Associate Editors}

Dr. Mandar Paingankar, Government Science College Gadchiroli, Maharashtra 442605, India

Dr. Ulrike Streicher, Wildlife Veterinarian, Eugene, Oregon, USA

Ms. Priyanka Iyer, ZOO/WILD, Coimbatore, Tamil Nadu 641035, India

Dr. B.A. Daniel, ZOO/WILD, Coimbatore, Tamil Nadu 641035, India

\section{Editorial Board}

Dr. Russel Mittermeier

Executive Vice Chair, Conservation International, Arlington, Virginia 22202, USA

\section{Prof. Mewa Singh Ph.D., FASc, FNA, FNASc, FNAPsy}

Ramanna Fellow and Life-Long Distinguished Professor, Biopsychology Laboratory, and Institute of Excellence, University of Mysore, Mysuru, Karnataka 570006, India; Honorary Professor, Jawaharlal Nehru Centre for Advanced Scientific Research, Bangalore; and Adjunct Professor, National Institute of Advanced Studies, Bangalore

\section{Stephen D. Nash}

Scientific Illustrator, Conservation International, Dept. of Anatomical Sciences, Health Sciences Center, T-8, Room 045, Stony Brook University, Stony Brook, NY 11794-8081, USA

\section{Dr. Fred Pluthero}

Toronto, Canada

\section{Dr. Priya Davidar}

Sigur Nature Trust, Chadapatti, Mavinhalla PO, Nilgiris, Tamil Nadu 643223, India

\section{Dr. Martin Fisher}

Senior Associate Professor, Battcock Centre for Experimental Astrophysics, Cavendish

Laboratory, JJ Thomson Avenue, Cambridge CB3 OHE, UK

\section{Dr. John Fellowes}

Honorary Assistant Professor, The Kadoorie Institute, 8/F, T.T. Tsui Building, The University of Hong Kong, Pokfulam Road, Hong Kong

\section{Prof. Dr. Mirco Solé}

Universidade Estadual de Santa Cruz, Departamento de Ciências Biológicas, Vice-coordenado do Programa de Pós-Graduação em Zoologia, Rodovia Ilhéus/Itabuna, Km 16 (45662-000)

Salobrinho, Ilhéus - Bahia - Brasil

\section{Dr. Rajeev Raghavan}

Professor of Taxonomy, Kerala University of Fisheries \& Ocean Studies, Kochi, Kerala, India

\section{English Editors}

Mrs. Mira Bhojwani, Pune, India

Dr. Fred Pluthero, Toronto, Canad

Mr. P. Ilangovan, Chennai, India

Web Development

Mrs. Latha G. Ravikumar, ZOO/WILD, Coimbatore, India

\section{Typesetting}

Mr. Arul Jagadish, ZOO, Coimbatore, India

Mrs. Radhika, ZOO, Coimbatore, India

Mrs. Geetha, ZOO, Coimbatore India
Fundraising/Communications

Mrs. Payal B. Molur, Coimbatore, India

Subject Editors 2018-2020

Fungi

Dr. B. Shivaraju, Bengaluru, Karnataka, India

Dr. R.K. Verma, Tropical Forest Research Institute, Jabalpur, India

Dr. Vatsavaya S. Raju, Kakatiay University, Warangal, Andhra Pradesh, India

Dr. M. Krishnappa, Jnana Sahyadri, Kuvempu University, Shimoga, Karnataka, India

Dr. K.R. Sridhar, Mangalore University, Mangalagangotri, Mangalore, Karnataka, India

Dr. Gunjan Biswas, Vidyasagar University, Midnapore, West Bengal, India

\section{Plants}

Dr. G.P. Sinha, Botanical Survey of India, Allahabad, India

Dr. N.P. Balakrishnan, Ret. Joint Director, BSI, Coimbatore, India

Dr. Shonil Bhagwat, Open University and University of Oxford, UK

Prof. D.J. Bhat, Retd. Professor, Goa University, Goa, India

Dr. Ferdinando Boero, Università del Salento, Lecce, Italy

Dr. Dale R. Calder, Royal Ontaro Museum, Toronto, Ontario, Canada

Dr. Cleofas Cervancia, Univ. of Philippines Los Baños College Laguna, Philippines

Dr. F.B. Vincent Florens, University of Mauritius, Mauritius

Dr. Merlin Franco, Curtin University, Malaysia

Dr. V. Irudayaraj, St. Xavier's College, Palayamkottai, Tamil Nadu, India

Dr. B.S. Kholia, Botanical Survey of India, Gangtok, Sikkim, India

Dr. Pankaj Kumar, Kadoorie Farm and Botanic Garden Corporation, Hong Kong S.A.R., China

Dr. V. Sampath Kumar, Botanical Survey of India, Howrah, West Bengal, India

Dr. A.J. Solomon Raju, Andhra University, Visakhapatnam, India

Dr. Vijayasankar Raman, University of Mississippi, USA

Dr. B. Ravi Prasad Rao, Sri Krishnadevaraya University, Anantpur, India

Dr. K. Ravikumar, FRLHT, Bengaluru, Karnataka, India

Dr. Aparna Watve, Pune, Maharashtra, India

Dr. Qiang Liu, Xishuangbanna Tropical Botanical Garden, Yunnan, China

Dr. Noor Azhar Mohamed Shazili, Universiti Malaysia Terengganu, Kuala Terengganu, Malaysia

Dr. M.K. Vasudeva Rao, Shiv Ranjani Housing Society, Pune, Maharashtra, India

Prof. A.J. Solomon Raju, Andhra University, Visakhapatnam, India

Dr. Mandar Datar, Agharkar Research Institute, Pune, Maharashtra, India

Dr. M.K. Janarthanam, Goa University, Goa, India

Dr. K. Karthigeyan, Botanical Survey of India, India

Dr. Errol Vela, University of Montpellier, Montpellier, France

Dr. P. Lakshminarasimhan, Botanical Survey of India, Howrah, India

Dr. Larry R. Noblick, Montgomery Botanical Center, Miami, USA

Dr. K. Haridasan, Pallavur, Palakkad District, Kerala, India

Dr. Analinda Manila-Fajard, University of the Philippines Los Banos, Laguna, Philippines

Dr. P.A. Sinu, Central University of Kerala, Kasaragod, Kerala, India

Dr. Afroz Alam, Banasthali Vidyapith (accredited A grade by NAAC), Rajasthan, India

Dr. K.P. Rajesh, Zamorin's Guruvayurappan College, GA College PO, Kozhikode, Kerala, India

Dr. David E. Boufford, Harvard University Herbaria, Cambridge, MA 02138-2020, USA

Dr. Ritesh Kumar Choudhary, Agharkar Research Institute, Pune, Maharashtra, India

Dr. Navendu Page, Wildlife Institute of India, Chandrabani, Dehradun, Uttarakhand, India

\section{Invertebrates}

Dr. R.K. Avasthi, Rohtak University, Haryana, India

Dr. D.B. Bastawade, Maharashtra, India

Dr. Partha Pratim Bhattacharjee, Tripura University, Suryamaninagar, India

Dr. Kailash Chandra, Zoological Survey of India, Jabalpur, Madhya Pradesh, India

Dr. Ansie Dippenaar-Schoeman, University of Pretoria, Queenswood, South Africa

Dr. Rory Dow, National Museum of natural History Naturalis, The Netherlands

Dr. Brian Fisher, California Academy of Sciences, USA

Dr. Richard Gallon, llandudno, North Wales, LL30 1UP

Dr. Hemant V. Ghate, Modern College, Pune, India

Dr. M. Monwar Hossain, Jahangirnagar University, Dhaka, Bangladesh

Mr. Jatishwor Singh Irungbam, Biology Centre CAS, Branišovská, Czech Republic.

Dr. Ian J. Kitching, Natural History Museum, Cromwell Road, UK

Dr. George Mathew, Kerala Forest Research Institute, Peechi, India

For Focus, Scope, Aims, and Policies, visit https://threatenedtaxa.org/index.php/JoTT/aims_scope
For Article Submission Guidelines, visit https://threatenedtaxa.org/index.php/JoTT/about/submissions
For Policies against Scientific Misconduct, visit https://threatenedtaxa.org/index.php/JoTT/policies_various

continued on the back inside cover 


\title{
The first record of Medog Gliding Frog Rhacophorus translineatus Wu, 1977 (Anura: Rhacophoridae) from Chhukha District, Bhutan
}

\author{
Sonam Lhendup ${ }^{1}$ (1) \& Bal Krishna Koirala ${ }^{2}$ (i) \\ ${ }^{1}$ Gedu Territorial Forest Division, Department of Forests and Park Services, Ministry of Agriculture and Forests, PB 21007, Chhuka, Bhutan. \\ ${ }^{2}$ Trashigang Forest Division, Department of Forests and Park Services, Ministry of Agriculture and Forests, PB 42001, Trashigang, Bhutan. \\ ${ }^{1}$ sonamlhendup20@gmail.com, ${ }^{2}$ bkgelephu@gmail.com (corresponding author)
}

\begin{abstract}
Rhacophorus is a genus of tree frogs in the family Rhacophoridae commonly referred to as parachuting or gliding frogs, distinguished by extensive digital webbing. A rare species, Rhacophorus translineatus Wu, 1977, was recorded for the first time in Bhutan. Information on morphological characters, geographical distribution, habitat and natural history notes is provided.
\end{abstract}

Keywords: Conservation status, distribution range, habitat, morphological characters, morphology, tree frongs.

Rhacophoridae is a large group of arboreal frogs containing 430 recognized species in 20 genera (Frost 2020). Of these, Rhacophorus Kuhl \& Van Hassalt, 1822 contains 44 species distributed across southern India to Bhutan and eastern Xizang (China) east and south to Hunan, Hainan, Yunnan \& Guangxi, through Myanmar, Thailand, Laos, Cambodia, Vietnam to Sumatra, Borneo, Sulawesi (Indonesia), and the Philippines (Frost 2020; AmphibiaWeb 2020).

In Bhutan, the Rhacophoridae are represented by four species: two from the genus Polypedates and two Rhacophorus species (Wangyal 2014; Das et al. 2016; Tshewang \& Letro 2018; Koirala et al. 2019). Rhacophorus smaragdinus (Blyth, 1852) formerly Rhacophorus maximus, was reported from Zhemgang (Wangyal 2014) and Jigme Dorji National Park (Koirala et al. 2016). In 2016, Rhacophorus bipunctatus Ahl, 1927 was reported from Royal Manas National Park (Das et al. 2016). Currently, the anuran fauna of Bhutan is represented by 83 recognized species distributed among seven genera (Das et al. 2016; Nidup et al. 2016; Tshewang \& Letro 2018; Koirala et al. 2019; Wangyal 2013, 2014; Tenzin \& Wangyal 2019; Wangyal \& Gurung 2017; Wangyal et at. 2020). These earlier studies did not provide evidential records of $R$. translineatus from Bhutan. $R$. translineatus was first described by Wu (Fei et al. 1977) and its type locality given as "Motuo, Xizang (= Tibet), China" was provided by Li et al. (2011). More than two decades after its first discovery in China in 1977, Bordoloi et al. (2002), and Borah \& Bordoloi (2004) reported R. translineatus from Dihang Dibang Biosphere Reserve, a new record for India.

The distribution range of $R$. translineatus is restricted to Medog county in Xizang (Tibet) autonomous region, China (Jiang \& Lau 2004), and the Indian state of Arunachal Pradesh (Saikia et al. 2017; Roy et al. 2018). Currently, 14 species of Rhacophorus are known to occur in countries neighboring India (Frost 2017), and nine are recorded from China (Pan et al. 2017). Here we present

Citation: Lhendup, S. \& B.K. Koirala (2021). The first record of Medog Gliding Frog Rhacophorus translineatus Wu, 1977 (Anura: Rhacophoridae) from Chhukha District, Bhutan. Journal of Threatened Taxa 13(13): 20078-20083. https://doi.org/10.11609/jott.6839.13.13.20078-20083

Copyright: (c) Lhendup \& Koirala 2021. Creative Commons Attribution 4.0 International License. JoTT allows unrestricted use, reproduction, and distribution of this article in any medium by providing adequate credit to the author(s) and the source of publication.

Funding: None.

Competing interests: The authors declare no competing interests.

Acknowledgements: We would like to express our heartfelt gratitude to Dr. Abhijit Das (Wildlife Institute of India) for helping us in species confirmation. We would like to thank Mr. Jigme Tenzin and Mr. Trshering who accompanied first author in field. We are also would like to kindly acknowledge Mr. Sonam Phuntsho (Forestry Officer) of Zhemzang Forest Division, for developing GIS map used in this publication. 
the first record of $R$. translineatus from Bhutan.

\section{MATERIALS AND MEthodS}

\section{Study area}

Gedu Territorial Forest Division covers entire Chhukha district (Figure 1) which lies within the 26.716$27.3^{\circ} \mathrm{N}$ and $89.250-89.816^{\circ} \mathrm{E}$. It borders with Samtse to the west, $\mathrm{Ha}$ to the north-west, Paro \& Thimphu to the north, and Dagana to the east. Towards the south, it borders with India. It covers an area of approximately $1,879.77 \mathrm{~km}^{2}$. The Chhukha district has an altitudinal range between 200 to $4,400 \mathrm{~m}$ and forest cover about $89.26 \%$ with corresponding vegetation types of tropical forest, sub-tropical forest, warm broadleaved forest, cool broadleaved forest, mixed conifer, and alpine meadows (RFMD 2017) that harbor rich repositories of biodiversity. Annual precipitation ranges from $750 \mathrm{~mm}$ in the north to $4,000 \mathrm{~mm}$ in the south (WCSD 2018).

The tropical and subtropical zone of the Chhukha experiences a hot summer with moderate to high rainfall, whereas in the warm temperate and cool temperate zones at higher altitudes, the climatic conditions are characterized by warm summers and cold winters. The higher region of the park is covered by perennial snow; a home of glacial rivers which serves as an important source of water for household use, agriculture and hydropower generation in the downstream valleys.

\section{Methods}

A single individual female of $R$. translineatus was observed by the first author in Gurung Dara, a hill district inhabited by the Gurung ethnic group in Chhukha district, Bhutan. Photographs were taken of the live specimen using a Canon EOS 80D digital camera, and locality data were collected using GPS (Garmin eTrex). The collected frog was euthanized humanely by using recommended dose of $(1.0 \mathrm{~g} / \mathrm{L})$ of maximum strength Orajel (Cecala et al. 2007) and fully sedated specimen was put to death by placing it in a $40 \%$ ethyl alcohol bath for 30 minutes. The specimen was fixed using $10 \%$ formalin and preserved in $75 \%$ ethanol. Beside the snout-vent length (SVL), which was made with a flexible ruler to the nearest $1 \mathrm{~mm}$, all other measurements of morphological characters were made with a digital slide caliper to the nearest $0.01 \mathrm{~mm}$. Since there is no standard system in the country to assign e-voucher number series; specimen was designated with

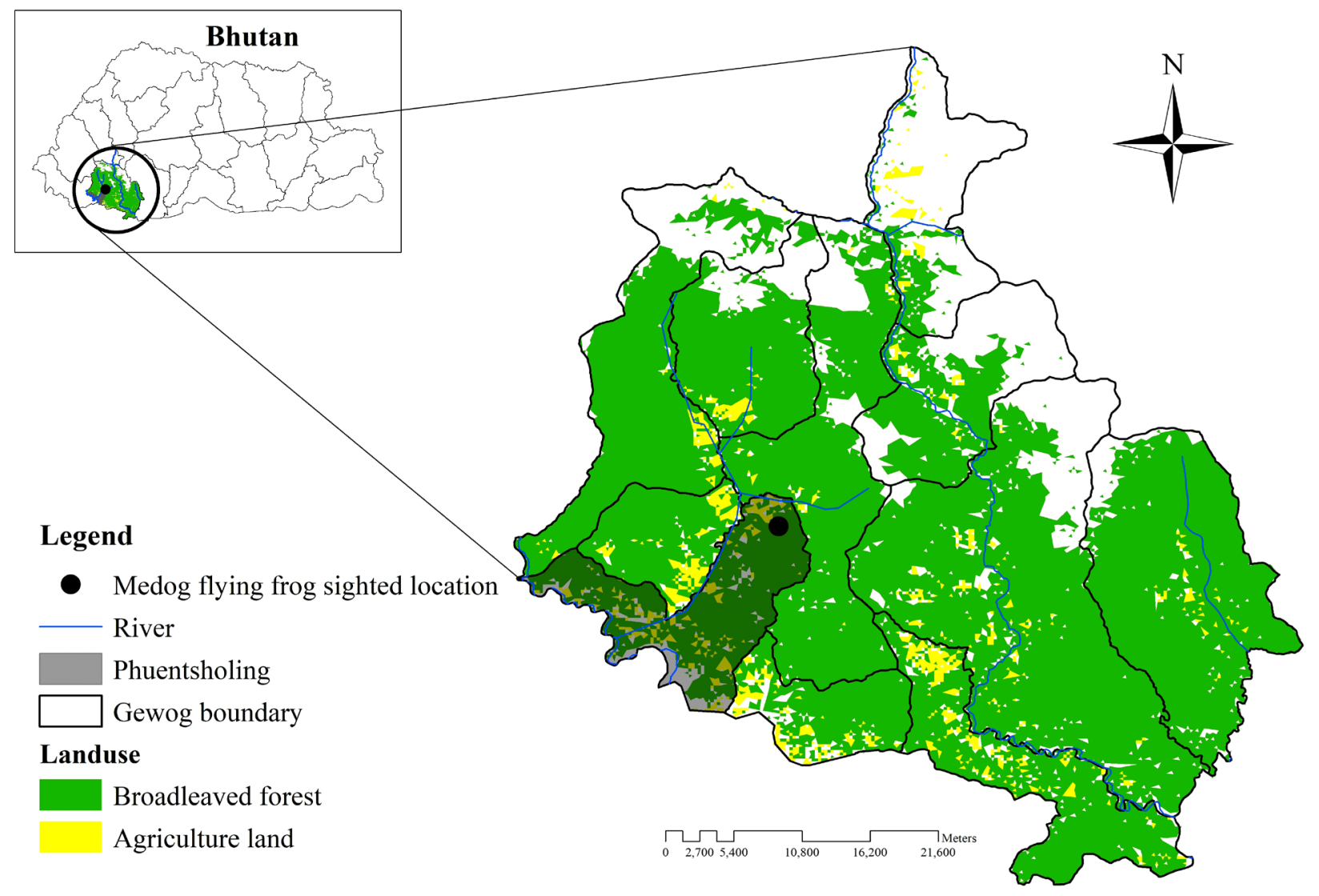

Figure 1. Map of study area. Phuntsholing geog, Chhukha district, Bhutan. 
field collection number and deposited by first author to Gedu Forest Division for future reference.

Terminology for morphological characters followed Li et al. (2011) and Watters et al. (2016). Abbreviations are as follows: SVL: Snout-vent length- measured from tip of snout to vent, HL: Head length-distance from the posterior jaws to the tip of the snout, HW: Head width-maximum distance between angle of jaws, IN: Internarial distance between inner margins of nostrils, IOD: Interorbital distance-minimum distance between upper eyelids, SL: Snout length- measured from anterior border of eye to tip of snout, ED: Eye diameterhorizontally from anterior to posterior corners of eye, UWE: Width of eyelid- greatest width of upper eyelid margin, TD: Tympanum diameter-greatest horizontal width of the tympanum, AGL: Axilla to Groin lengthmeasured from posterior base of forelimb to anterior base of hindlimb, DNE: nostril-eye length- measured from nostril to eye, THL: Thigh length- distance from vent to knee, TIL: Tibia length- distance from knee to foot, LAL: Lower arm length- distance from the elbow to the tip of Finger III, UAL: Upper arm length-measured from the axilla to the elbow, FAL: Forearm length- from the flexed elbow to the base of the outer palmar tubercle, HAL: Hind limb length- from vent to tip of longest toe, FLL: Forelimb length- measured from axilla to tip of disk of finger III, FL: Foot length- measured from proximal end of inner metatarsal tubercle to tip of toe IV, HTL: TRL- Tarsus length; Hand length- base of outer palmer tubercle to tip of finger III.

\section{RESULTS}

Specimen examined: Field collection No (GFD. AMP.20.001), R. translineatus (Figure 2) an adult female collected on 9 July 2020, at 2230 h from Gurung Dara $\left(26.972^{\circ} \mathrm{N}\right.$ and $\left.89.452^{\circ} \mathrm{E}\right)$, WGS84, elevation $1,727 \mathrm{~m}$ ) in Phuntsholing geog (geog= sub district), Gedu Territorial Forest Division, Chhukha district, Bhutan.

\section{Morphology and measurements}

Currently reported $R$. translineatus was compared with morphological characters of $R$. translineatus presented in literatures (Table 1 ). Dorsally light brown in colour (Image 1); very fine granules on dorsum with 11 narrow transverse dark brown line from snout to vent (Image 2A); head flat, longer than broad; tympanum distinct; eye large, pupil is horizontally oval (Image 2B); tip of the snout is pointed, protruding forward; ventrally whitish with series of markings; second, third, and fourth fingers near full webbed, toes fully webbed (Image 2C); ventrolaterally marked with a series of white spots; hind

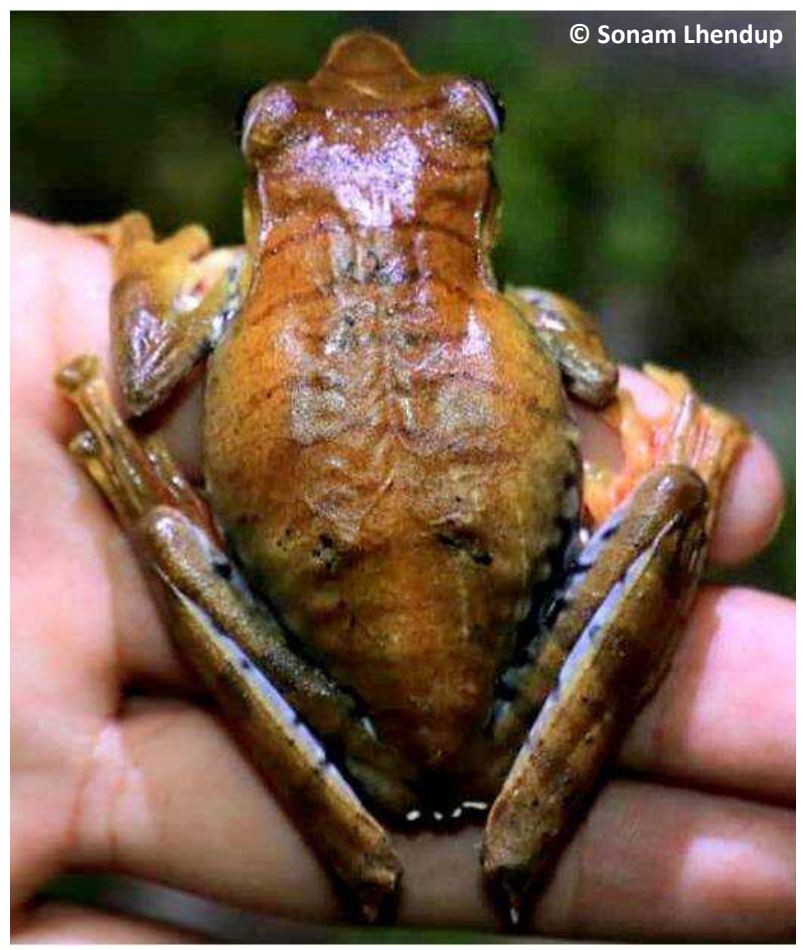

Image 1. Rhacophorus translineatus recorded from Gurung Dara, Gedu Forest Division, Chhukha Bhutan.

Table 1. Comparison of morphological characters of currently studied R. translineatus with the Holotype (CIB 73II0031), type locality: Motuo, Xizang (= Tibet), China. Data taken from (Li et al. 2011). "-" indicates data unavailable.

\begin{tabular}{|c|c|c|}
\hline $\begin{array}{l}\text { Characters } \\
\text { (in } \mathrm{mm} \text { ) }\end{array}$ & $\begin{array}{c}\text { Currently studied } R \text {. } \\
\text { translineatus } \\
\text { Field collection No: GFD. } \\
\text { AMP.20.001 }\end{array}$ & $\begin{array}{l}\text { R. translineatus } \\
\text { Holotype: CIB } \\
73110031\end{array}$ \\
\hline SVL & 66.50 & 54.68 \\
\hline $\mathrm{HL}$ & 22.10 & 18.10 \\
\hline HW & 18.35 & 16.38 \\
\hline IND & 6.08 & 5.04 \\
\hline IOD & 7.01 & 5.57 \\
\hline SL & 9.89 & 9.75 \\
\hline ED & 6.10 & 5.57 \\
\hline UWE & 5.40 & - \\
\hline TD & 2.95 & 1.97 \\
\hline AGL & 35.56 & - \\
\hline DNE & 5.20 & 4.46 \\
\hline THL & 33.50 & 23.54 \\
\hline TIL & 36.07 & 26.68 \\
\hline LAL & 32.81 & 26.28 \\
\hline UAL & 15.50 & - \\
\hline FAL & 14.03 & - \\
\hline HLL & 116.50 & - \\
\hline FLL & 48.31 & - \\
\hline $\mathrm{FL}$ & 28.71 & 25.61 \\
\hline HTL & 18.78 & 18.11 \\
\hline TRL & 18.22 & - \\
\hline
\end{tabular}



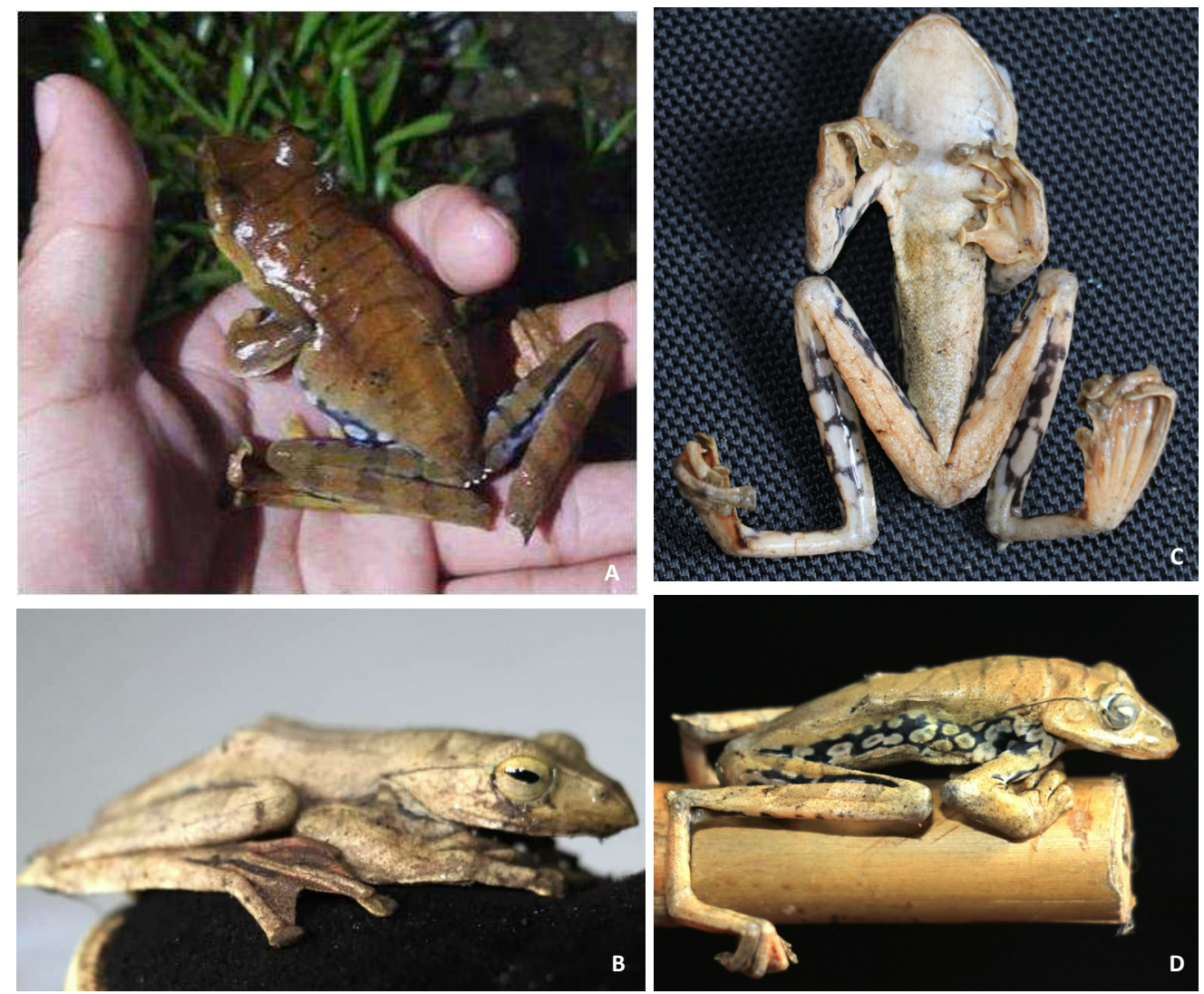

Image 2. Rhacophorus translineatus recorded from Chuuka district: A-Dorsal view of live specimen | B-Lateral view of live specimen | CVentral view of preserved specimen | D-Lateral view of preserved specimen. (C) Sonam Lhendup.

limbs are slender (Image 2D).

\section{Distribution and natural history}

Besides having its distribution in China and India, this species is currently known from Gurung Dara, Phuntsholing geog, Chhukha District, Bhutan. In Bhutan, unless otherwise stated, $R$. translineatus is found up to an elevation of $1,727 \mathrm{~m}$. This record raises the upper elevation limit which was previously reported for the species from Motuo, Xizang (= Tibet), China as 1,2001,500 m (Li et al. 2011) and Tiwarigaon and the Ahini Ango, Dibang River Basin, Arunachal Pradesh, India, as 920-1,480 m (Roy et al. 2018). The single individual was collected from water catchment area of Tomi River, one of the tributaries of Toorsa River which ultimately enters into the Indian state of West Bangal via Phountsholing. The frog was on farm road, situated close proximity to small seasonal freshwater pond when it was first sighted. The immediate micro-habitat was small seasonal freshwater pool surrounded by marshy, abandoned agriculture fallow land currently being used for cattle grazing by local inhabitants. The macro habitat type is characterized by forested hill represented by subtropical broadleaved forest, mostly dominated by Nepal Alder Alnus nepalensis, Red Cedar Toona ciliata, Needle Wood Tree Schima wallichii, Chinquapin Tree Castanopsis sp., and Symplocos sp. The observed vegetation types and altitudinal gradient of specific site falls in subtropical zone of Bhutan, based on vegetation types described by Ohsawa (1978) for Bhutan.

\section{Discussion}

In 2000 Das \& Palden (2000) reported seven amphibians from three families: 1 megophryid, 1 bufonid, and 5 ranids, all new records for Bhutan. After a comprehensive review of the Bhutanese herpetological literature, 35 confirmed species of anurans were reported to occur in Bhutan until 2014 (Wangyal 2014). Subsequently in 2016, a species of Cascade Frog Amolopos himalayanus (Boulenger, 1888) was reported as first record for Bhutan by Nidup et al. (2016) from Trashigang district. In the same year two more anurans species $R$. bipunctatus and Uperodon globulosus (Günther, 1864) were reported by Das et al. (2016) from Royal Manas National Park as new records for Bhutan. Until 2017, Bhutan was represented by 59 species of 
amphibians (Wangyal \& Gurung 2017). Subsequently, two species of amphibian viz., Polypedates teraiensis and Leptobrachium bompu Sondhi \& Ohler, 2011 were added as new records for Bhutan (Tshewang \& Letro 2018; Tenzin \& Wangyal 2019). An addition of 22 new records by Wangyal et al. (2020) increased the amphibian checklist of Bhutan to 83 recognized species. The current record of Rhacophorus translineatus demonstrates that Bhutan is now home to at least 84 confirmed species of amphibian.

Historically, due to the rugged terrain, cold climatic conditions, and largely inaccessible landscape, the biological diversity of eastern Himalaya remained largely unexplored. Herpetofauna have received disproportionate scientific attention compared to large vertebrates since conservation efforts began in Bhutan. In recent decades the frequent discovery of new species and new range extensions in the eastern Himalayas demonstrates a serious need for further exploration in the region. The Himalayan foothills, the locality of currently observed $R$. translineatus, shares similar bio-geographic elements of the eastern Himalayan locations from where most of the Rhacophorus species including $R$. translineatus have been reported. However, altitudinal boundary extension demonstrated by currently observed $R$. translineatus was relatively higher than altitudinal records previously reported as, 920-1,500 m (Li et al. 2011; Roy et al. 2018). This first record of $R$. translineatus from Bhutan raises a total of 84 confirmed species of anurans in Bhutan. In addition, it also provides vital information on new distribution range of this species in Bhutan besides China and India.

\section{Conservation status}

The IUCN (2004) has assessed $R$. translineatus as a Data Deficient (DD) species in view of continuing uncertainties as to its extent of occurrence, ecological requirements, and its unknown population trend (Jiang \& Lau 2004). Data Deficient species must be given high research priority as most of such species often receive disproportionate scientific attention, contributing to uncertainty in estimates of extinction risk. Currently, information on its habitat requirement is very scanty; however present study revealed that the species is adaptable to human modified landscape particularly associated with agriculture development. Although there is no adequate evidence to ascertain whether the species is facing survival threat within its present locality, but in general, amphibians are perceived to be more threatened in human dominated landscape and response rapidly to environmental change. Therefore, a more holistic, education-focused conservation strategy combined with ecological research may be needed for more effective conservation of the amphibian fauna of Bhutan.

\section{REFERENCES}

AmphibiaWeb (2020). University of California, Berkeley, CA, USA. Accessed on 12 Aug 2020. Available at https://amphibiaweb.org/

Borah, M.M. \& S. Bordoloi (2004). Altitudinal distribution pattern of Amphibian fauna of Arunachal Pradesh with special reference to Dehang-Debang Biosphere Reserve, Arunachal Pradesh, India. Himalayan Biosphere Reserve Bulletin 5: 51-55.

Bordoloi, S., M.M. Borah, P.K. Sharmah \& J. Sharmah (2002). Amphibian and insect fauna of amphibian habitats of DehangDebang Biosphere Reserve, Arunachal Pradesh. Himalayan Biosphere Reserves Bulletin 4: 33-38.

Cecala, K.K., S.J. Price \& M.E. Dorcas (2007). A comparison of the effectiveness of recommended doses of MS222 (tricaine methanesulfonate) and Orajel (benzocaine) for amphibian anesthesia. Herpetological Review 38: 63-66.

Das, A., P. Sharma, H. Surendran, A. Nath, S. Ghosh, D. Dutta, J. Mondol \& Y. Wangdi (2016). Additions to the herpetofauna of Royal Manas National Park, Bhutan, with six new country records. Herpetology Notes 9: 261-278.

Das, I. \& J. Palden (2000). Herpetological collection from Bhutan, with new country records. Herpetological Review 31: 256-258.

IUCN (2004). The IUCN Red List of Threatened Species. Version 2004 -3.1 Accessed on 30 April 2004. Available at Available at http:// www.iucnredlist.org/.

Liang, F. \& M.W.N. Lau (2004). Rhacophorus translineatus. The IUCN Red List of Threatened Species. Available at http://www.iucnredlist. org/

Fei, L., C.Y. Ye, G.F. Wu \& S.Q. Hu (1977). A survey of amphibians in Xizang (Tibet). Acta Herpetologica Sinica 23: 59-63.

Forest Recourses Management Division (2017). Land Use and Land Cover of Bhutan 2016, Maps and Statistics. Department of Forests and Park Services, Thimphu, $21 \mathrm{pp}$.

Frost, D.R. (2020). Amphibian Species of the World: an Online Reference. Version 6.1 (accessed 10 August 2020). Electronic Database. American Museum of Natural History, New York, USA. Accessible at http://research.amnh.org/herpetology/amphibia/ index.html

Koirala, B.K., K. Cheda \& T. Penjor (2019). Species diversity and spatial distribution of amphibian fauna along the altitudinal gradients in Jigme Dorji National Park, western Bhutan. Journal of Threatened Taxa 11: 14249-14258. https://doi.org/10.11609/ jott.4944.11.10.14249-14258

LI, J., Y. Chen, S. Li, K. LV \& Y. Wang (2011). Catalogue of the type specimens of amphibians and reptiles in the Herpetological Museum of Chengdu Institute of Biology, Chinese Academy of Sciences: I. Rhacophoridae (Anura, Amphibia). Asian Herpetological Research 2: 129-141.

Nidup, T., D. Gyeltshen, Penjor, S. Dorji \& M.J. Pearch (2016). The first record of Amolops himalayanus (Anura: Ranidae) from Bhutan. The Herpetological Bulletin 136: 13-18.

Ohler, A. \& K. Deuti (2018). Polypedates smaragdinus Blyth, 1852-a senior subjective synonym of Rhacophorus maximus Günther, 1858. Zootaxa 4375: 273-280.

Ohsawa, M. (1987). Vegetation zones in the Bhutan Himalaya. In: Ohsawa M. (ed.), Life Zone Ecology of Bhutan Himalaya II. Chiba University, Japan, 206 pp.

Pan, T., Y. Zhang, H. Wang, J. Wu, X. Kang, L. Qian, K. Li, Y. Zhang, J. Chen, D. Rao, J. Jiang \& B. Zhang (2017). A New Species of the Genus Rhacophorus (Anura: Rhacophoridae) from Dabie Mountains in East China. Asian Herpetological Research 8: 1-13. 
Roy, J.K., R.H. Begum \& M.F. Ahmed (2018). Amphibians of the Dibang River Basin, Arunachal Pradesh: an annotated checklist with distribution records. Journal of Threatened Taxa 10(15): 1294012952. https://doi. org/10.11609/jott.4249.10.15.12940-12952

Saikia, B., P. Nanda \& B. Sinha (2017). Atlas of endemic Rhacophorus (Amphibia: Anura) of north east India. Bulletin of Arunachal Forest Research 32(1\&2): 91-95.

Tenzin, J. \& J.T. Wangyal (2019). New record of Blue-eyed Eastern Spadefoot Toad Leptobrachium bompu (Amphibia: Megophryidae) from Sarpang District in Bhutan. Journal of Threatened Taxa 11(3) 13385-13389. https://doi.org/10.11609/jott.4134.11.3.1338513389

Tshewang, S. \& L. Letro (2018). The herpetofauna of Jigme Singye Wangchuck National Park in central Bhutan: status, distribution and new records. Journal of Threatened Taxa 10(11): 12489-12498. https://doi.org/10.11609/jott.3849.10.11.12489-12498

Wangyal, J.T., D.S. Bower, Sherub, S. Tshewang, D. Wangdi, K. Rinchen, S. Phuntsho, C. Tashi, B.K. Koirala, Gyeltshen, G.S. Bhandari, S. Jamtsho, Y. Phuntsho, T.P. Koirala, B.B. Ghalley, L. Chaida, J. Tenzin, R.B. Powrel, R. Tshewang, O.N. Raika, S. Jamtsho, Kinley, Gyeltshen, S. Tashi, D. Nidup, N. Wangdi, Phuntsho, L. Norbu, K. Wangdi, T. Wangchuk, P. Tobgay, T. Dorji \& I. Das (2020).
New herpetofaunal records from the Kingdom of Bhutan obtained through citizen science. Herpetological Review 51(4): 790-798.

Wangyal, J.T. \& D.B. Gurung (2017). The Current Status of Herpetofauna in Bhutan, pp. 39-55. In: Gurung, D.B. \& O. Katel (ed.). Introduction to the Biodiversity of Bhutan in the Context of Climate Change and Economic Development. Centre for Rural Development Studies. College of Natural Resources, Lobesa, Punakha. Kuensel Corporation Limited, 200 pp.

Wangyal, J.T. (2013). New records of reptiles and amphibians from Bhutan. Journal of Threatened Taxa 5(13): 4774-4783. https://doi. org/10.11609/JoTT.03539.4774-83.

Wangyal, J.T. (2014). The status of herpetofauna of Bhutan. Journal of the Bhutan Ecological Society 1: 20-25.

Wangyal, J.T. \& D.B. Gurung (2012). Amphibians of Punakha-Wangdue Phodrang Valley, Bhutan. Frog leg 18: 31- 44.

Watters, J.L., S.T. Cummings, R.L. Flanagan \& C.D. Siler (2016). Review of morphometric measurements used in anuran species descriptions and recommendations for a standardized approach. Zootaxa 4072: 477-495.

Weather and Climate Services Division (2018). Climate Data Book of Bhutan. National Centre for Hydrology and Meteorology. Royal Government of Bhutan, $255 \mathrm{pp}$ 
Dr. John Noyes, Natural History Museum, London, UK

Dr. Albert G. Orr, Griffith University, Nathan, Australia

Dr. Sameer Padhye, Katholieke Universiteit Leuven, Belgium

Dr. Nancy van der Poorten, Toronto, Canada

Dr. Kareen Schnabel, NIWA, Wellington, New Zealand

Dr. R.M. Sharma, (Retd.) Scientist, Zoological Survey of India, Pune, India

Dr. Manju Siliwal, WILD, Coimbatore, Tamil Nadu, India

Dr. G.P. Sinha, Botanical Survey of India, Allahabad, India

Dr. K.A. Subramanian, Zoological Survey of India, New Alipore, Kolkata, India

Dr. P.M. Sureshan, Zoological Survey of India, Kozhikode, Kerala, India

Dr. R. Varatharajan, Manipur University, Imphal, Manipur, India

Dr. Eduard Vives, Museu de Ciències Naturals de Barcelona, Terrassa, Spain

Dr. James Young, Hong Kong Lepidopterists' Society, Hong Kong

Dr. R. Sundararaj, Institute of Wood Science \& Technology, Bengaluru, India

Dr. M. Nithyanandan, Environmental Department, La Ala Al Kuwait Real Estate. Co. K.S.C.,

Kuwait

Dr. Himender Bharti, Punjabi University, Punjab, India

Mr. Purnendu Roy, London, UK

Dr. Saito Motoki, The Butterfly Society of Japan, Tokyo, Japan

Dr. Sanjay Sondhi, TITLI TRUST, Kalpavriksh, Dehradun, India

Dr. Nguyen Thi Phuong Lien, Vietnam Academy of Science and Technology, Hanoi, Vietnam

Dr. Nitin Kulkarni, Tropical Research Institute, Jabalpur, India

Dr. Robin Wen Jiang Ngiam, National Parks Board, Singapore

Dr. Lional Monod, Natural History Museum of Geneva, Genève, Switzerland.

Dr. Asheesh Shivam, Nehru Gram Bharti University, Allahabad, India

Dr. Rosana Moreira da Rocha, Universidade Federal do Paraná, Curitiba, Brasi

Dr. Kurt R. Arnold, North Dakota State University, Saxony, Germany

Dr. James M. Carpenter, American Museum of Natural History, New York, USA

Dr. David M. Claborn, Missouri State University, Springfield, USA

Dr. Kareen Schnabel, Marine Biologist, Wellington, New Zealand

Dr. Amazonas Chagas Júnior, Universidade Federal de Mato Grosso, Cuiabá, Brasil

Mr. Monsoon Jyoti Gogoi, Assam University, Silchar, Assam, India

Dr. Heo Chong Chin, Universiti Teknologi MARA (UiTM), Selangor, Malaysia

Dr. R.J. Shiel, University of Adelaide, SA 5005, Australia

Dr. Siddharth Kulkarni, The George Washington University, Washington, USA

Dr. Priyadarsanan Dharma Rajan, ATREE, Bengaluru, India

Dr. Phil Alderslade, CSIRO Marine And Atmospheric Research, Hobart, Australia

Dr. John E.N. Veron, Coral Reef Research, Townsville, Australia

Dr. Daniel Whitmore, State Museum of Natural History Stuttgart, Rosenstein, Germany.

Dr. Yu-Feng Hsu, National Taiwan Normal University, Taipei City, Taiwan

Dr. Keith V. Wolfe, Antioch, California, USA

Dr. Siddharth Kulkarni, The Hormiga Lab, The George Washington University, Washington,

D.C., USA

Dr. Tomas Ditrich, Faculty of Education, University of South Bohemia in Ceske

Budejovice, Czech Republic

Dr. Mihaly Foldvari, Natural History Museum, University of Oslo, Norway

Dr. V.P. Uniyal, Wildlife Institute of India, Dehradun, Uttarakhand 248001, India

Dr. John T.D. Caleb, Zoological Survey of India, Kolkata, West Bengal, India

Dr. Priyadarsanan Dharma Rajan, Ashoka Trust for Research in Ecology and the Environment

(ATREE), Royal Enclave, Bangalore, Karnataka, India

\section{Fishes}

Dr. Neelesh Dahanukar, IISER, Pune, Maharashtra, India

Dr. Topiltzin Contreras MacBeath, Universidad Autónoma del estado de Morelos, México

Dr. Heok Hee Ng, National University of Singapore, Science Drive, Singapore

Dr. Rajeev Raghavan, St. Albert's College, Kochi, Kerala, India

Dr. Robert D. Sluka, Chiltern Gateway Project, A Rocha UK, Southall, Middlesex, UK

Dr. E. Vivekanandan, Central Marine Fisheries Research Institute, Chennai, India

Dr. Davor Zanella, University of Zagreb, Zagreb, Croatia

Dr. A. Biju Kumar, University of Kerala, Thiruvananthapuram, Kerala, India

Dr. Akhilesh K.V., ICAR-Central Marine Fisheries Research Institute, Mumbai Research

Centre, Mumbai, Maharashtra, India

Dr. J.A. Johnson, Wildlife Institute of India, Dehradun, Uttarakhand, India

Amphibians

Dr. Sushil K. Dutta, Indian Institute of Science, Bengaluru, Karnataka, India

Dr. Annemarie Ohler, Muséum national d'Histoire naturelle, Paris, France

\section{Reptiles}

Dr. Gernot Vogel, Heidelberg, Germany

Dr. Raju Vyas, Vadodara, Gujarat, India

Dr. Pritpal S. Soorae, Environment Agency, Abu Dubai, UAE.

Prof. Dr. Wayne J. Fuller, Near East University, Mersin, Turkey

Prof. Chandrashekher U. Rivonker, Goa University, Taleigao Plateau, Goa. India

Dr. S.R. Ganesh, Chennai Snake Park, Chennai, Tamil Nadu, India

Dr. Himansu Sekhar Das, Terrestrial \& Marine Biodiversity, Abu Dhabi, UAE
Birds

Dr. Hem Sagar Baral, Charles Sturt University, NSW Australia

Dr. Chris Bowden, Royal Society for the Protection of Birds, Sandy, UK

Dr. Priya Davidar, Pondicherry University, Kalapet, Puducherry, India

Dr. J.W. Duckworth, IUCN SSC, Bath, UK

Dr. Rajah Jayapal, SACON, Coimbatore, Tamil Nadu, India

Dr. Rajiv S. Kalsi, M.L.N. College, Yamuna Nagar, Haryana, India

Dr. V. Santharam, Rishi Valley Education Centre, Chittoor Dt., Andhra Pradesh, India

Dr. S. Balachandran, Bombay Natural History Society, Mumbai, India

Mr. J. Praveen, Bengaluru, India

Dr. C. Srinivasulu, Osmania University, Hyderabad, India

Dr. K.S. Gopi Sundar, International Crane Foundation, Baraboo, USA

Dr. Gombobaatar Sundev, Professor of Ornithology, Ulaanbaatar, Mongolia

Prof. Reuven Yosef, International Birding \& Research Centre, Eilat, Israel

Dr. Taej Mundkur, Wetlands International, Wageningen, The Netherlands

Dr. Carol Inskipp, Bishop Auckland Co., Durham, UK

Dr. Tim Inskipp, Bishop Auckland Co, Durham, UK

Dr. V. Gokula, National College, Tiruchirappalli, Tamil Nadu, India

Dr. Arkady Lelej, Russian Academy of Sciences, Vladivostok, Russia

Dr. Simon Dowell, Science Director, Chester Zoo, UK

Dr. Mário Gabriel Santiago dos Santos, Universidade de Trás-os-Montes e Alto Douro,

Quinta de Prados, Vila Real, Portugal

Dr. Grant Connette, Smithsonian Institution, Royal, VA, USA

Dr. M. Zafar-ul Islam, Prince Saud Al Faisal Wildlife Research Center, Taif, Saudi Arabia

Mammals

Dr. Giovanni Amori, CNR - Institute of Ecosystem Studies, Rome, Italy

Dr. Anwaruddin Chowdhury, Guwahati, India

Dr. David Mallon, Zoological Society of London, UK

Dr. Shomita Mukherjee, SACON, Coimbatore, Tamil Nadu, India

Dr. Angie Appel, Wild Cat Network, Germany

Dr. P.O. Nameer, Kerala Agricultural University, Thrissur, Kerala, India

Dr. Ian Redmond, UNEP Convention on Migratory Species, Lansdown, UK

Dr. Heidi S. Riddle, Riddle's Elephant and Wildlife Sanctuary, Arkansas, USA

Dr. Karin Schwartz, George Mason University, Fairfax, Virginia.

Dr. Lala A.K. Singh, Bhubaneswar, Orissa, India

Dr. Mewa Singh, Mysore University, Mysore, India

Dr. Paul Racey, University of Exeter, Devon, UK

Dr. Honnavalli N. Kumara, SACON, Anaikatty P.O., Coimbatore, Tamil Nadu, India

Dr. Nishith Dharaiya, HNG University, Patan, Gujarat, India

Dr. Spartaco Gippoliti, Socio Onorario Società Italiana per la Storia della Fauna "Giuseppe

Altobello", Rome, Italy

Dr. Justus Joshua, Green Future Foundation, Tiruchirapalli, Tamil Nadu, India

Dr. H. Raghuram, The American College, Madurai, Tamil Nadu, India

Dr. Paul Bates, Harison Institute, Kent, UK

Dr. Jim Sanderson, Small Wild Cat Conservation Foundation, Hartford, USA

Dr. Dan Challender, University of Kent, Canterbury, UK

Dr. David Mallon, Manchester Metropolitan University, Derbyshire, UK

Dr. Brian L. Cypher, California State University-Stanislaus, Bakersfield, CA

Dr. S.S. Talmale, Zoological Survey of India, Pune, Maharashtra, India

Prof. Karan Bahadur Shah, Budhanilakantha Municipality, Kathmandu, Nepal

Dr. Susan Cheyne, Borneo Nature Foundation International, Palangkaraja, Indonesia

Dr. Hemanta Kafley, Wildlife Sciences, Tarleton State University, Texas, USA

\section{Other Disciplines}

Dr. Aniruddha Belsare, Columbia MO 65203, USA (Veterinary)

Dr. Mandar S. Paingankar, University of Pune, Pune, Maharashtra, India (Molecular)

Dr. Jack Tordoff, Critical Ecosystem Partnership Fund, Arlington, USA (Communities)

Dr. Ulrike Streicher, University of Oregon, Eugene, USA (Veterinary)

Dr. Hari Balasubramanian, EcoAdvisors, Nova Scotia, Canada (Communities)

Dr. Rayanna Hellem Santos Bezerra, Universidade Federal de Sergipe, São Cristóvão, Brazil

Dr. Jamie R. Wood, Landcare Research, Canterbury, New Zealand

Dr. Wendy Collinson-Jonker, Endangered Wildlife Trust, Gauteng, South Africa

Dr. Rajeshkumar G. Jani, Anand Agricultural University, Anand, Gujarat, India

Dr. O.N. Tiwari, Senior Scientist, ICAR-Indian Agricultural Research Institute (IARI), New

Delhi, India

Dr. L.D. Singla, Guru Angad Dev Veterinary and Animal Sciences University, Ludhiana, India

Dr. Rupika S. Rajakaruna, University of Peradeniya, Peradeniya, Sri Lanka

Dr. Bahar Baviskar, Wild-CER, Nagpur, Maharashtra 440013, India

Reviewers 2018-2020

Due to pausity of space, the list of reviewers for $2018-2020$ is available online.

The opinions expressed by the authors do not reflect the views of the Journal of Threatened Taxa, Wildlife Information Liaison Development Society, Zoo Outreach Organization, or any of the partners. The journal, the publisher, the host, and the partners are not responsible for the accuracy of the political boundaries shown in the maps by the authors.

Journal of Threatened Taxa is indexed/abstracted in Bibliography of Systematic Mycology, Biological Abstracts, BIOSIS Previews, CAB Abstracts, EBSCO, Google Scholar, Index Copernicus, Index Fungorum, JournalSeek, National Academy of Agricultural Sciences, NewJour, OCLC WorldCat, SCOPUS, Stanford University Libraries, Virtual Library of Biology, Zoological Records.

NAAS rating (India) 5.64
Print copies of the Journal are available at cost. Write to:

The Managing Editor, JoTT,

c/o Wildlife Information Liaison Development Society,

No. 12, Thiruvannamalai Nagar, Saravanampatti - Kalapatti Road,

Saravanampatti, Coimbatore, Tamil Nadu 641035, India

ravi@threatenedtaxa.org 


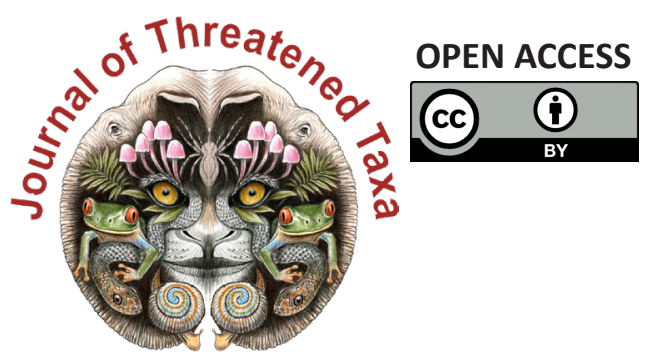

www.threatenedtaxa.org

The Journal of Threatened Taxa (JoTT) is dedicated to building evidence for conservation globally by publishing peer-reviewed articles online every month at a reasonably rapid rate at www.threatenedtaxa.org. All articles published in JoTT are registered under Creative Commons Attribution 4.0 International License unless otherwise mentioned. JoTT allows allows unrestricted use, reproduction, and distribution of articles in any medium by providing adequate credit to the author(s) and the source of publication.

ISSN 0974-7907 (Online) I ISSN $0974-7893$ (Print)

\section{November 2021 | Vol. 13 | No. 13 | Pages: 19887-20142 \\ Date of Publication: 26 November 2021 (Online \& Print) DOI: 10.11609/jott.2021.13.13.19887-20142}

\section{Article}

An inventory of geometrid moths (Lepidoptera: Geometroidea: Geometridae) of KalakadMundanthurai Tiger Reserve, India

- Geetha Iyer, Dieter Stüning \& Sanjay Sondhi, Pp. 19887-19920

\section{Communications}

Roadkills of Lowland Tapir Tapirus terrestris (Mammalia: Perissodactyla: Tapiridae) in one of its last refuges in the Atlantic Forest

- Aureo Banhos, Andressa Gatti, Marcelo Renan de Deus Santos, Leonardo Merçon,

Ilka Westermeyer, Natália Carneiro Ardente, Luis Francisco Oliveira Pereira Gonzaga, Lucas Mendes Barreto, Lucas Damásio, Tomas Lima Rocha, Vitor Roberto Schettino, Renata Valls, Helena Godoy Bergallo, Marcos Vinicius Freitas Silva, Athelson Stefanon Bittencourt, Danielle de Oliveira Moreira \& Ana Carolina Srbek-Araujo, Pp. 19921-19929

Scientific contributions and learning experiences of citizen volunteers with a small cat project in Sanjay Gandhi National Park, Mumbai, India

- Shomita Mukherjee, R. Nandini, P.V. Karunakaran \& Nayan Khanolkar, Pp. 19930-19936

Seasonal food preferences and group activity pattern of Blackbuck Antilope cervicapra (L., 1758) (Mammalia: Cetartiodactyla: Bovidae) in a semi-arid region of western Haryana, India

- Vikram Delu, Dharambir Singh, Sumit Dookia, Priya \& Kiran, Pp. 19937-19947

Studies on the habitats of Grey Francolin Francolinus pondicerianus (J.F. Gmelin, 1789) (Galliformes: Phasianidae) in northern districts of Tamil Nadu, India

- M. Pandian, Pp. 19948-19955

Recovery of vulture population in roosting and scavenging areas of Bastar and Bijapur, Chhattisgarh, India

- Sushil Kumar Dutta, Muntaz Khan, P.R.S. Nagi, Santosh Durgam \& Surabhi Dutta, Pp. 19956-19963

A geographical assessment of Chariganga and Arpara Beel (wetlands) of Nadia, West Bengal as a habitat of wetland birds

- Mehedi Hasan Mandal, Arindam Roy \& Giyasuddin Siddique, Pp. 19964-19975

Phenotypic plasticity in Barilius vagra (Hamilton, 1822) (Teleostei: Danionidae) from two geographically distinct river basins of Indian Himalaya

- Sumit Kumar, Sharali Sharma \& Deepak Singh, Pp. 19976-19984

Taxonomic notes, a new species, and a key to Indian species of the click beetle genus Cryptalaus Ôhira, 1967 (Coleoptera: Elateridae: Agrypninae)

- Harshad Parekar \& Amol Patwardhan, Pp. 19985-19999

Niche overlap of benthic macrofauna in a tropical estuary: diurnal variation

- Mário Herculano de Oliveira, Lidiane Gomes de Lima, Caroline Stefani da Silva Lima, Jéssica de Oliveira Lima Gomes, Franciely Ferreira Paiva, Graciele de Barros, Carlinda Railly Medeiros \& Joseline Molozzi, Pp. 20000-20010

Diversity of aquatic insects and biomonitoring of water quality in the upper Ganga River, a Ramsar site: a preliminary assessment

- Kritish De, Arkojyoti Sarkar, Kritika Singh, Virendra Prasad Uniyal, Jeyaraj Antony Johnson \& Syed Ainul Hussain, Pp. 20011-20018

Patterns of forest cover loss in the terrestrial Key Biodiversity Areas in the Philippines: critical habitat conservation priorities

- Bernard Peter O. Daipan, Pp. 20019-20032

The woody flora of Shettihalli Wildlife Sanctuary, central Western Ghats of Karnataka, India - A checklist

- Kanda Naveen Babu, Kurian Ayushi, Vincy K. Wilson, Narayanan Ayyappan \&

Narayanaswamy Parthasarathy, Pp. 20033-20055

Reproductive biology of Ophiorrhiza caudata C.E.C.Fisch. (Rubiaceae), an endemic and endangered creeping perennial herb of the Western Ghats, India

- Maria Theresa, Appukuttan Kamalabai Sreekala \& Jayalakshmi Mohanlal, Pp. 20056-20065
Short Communications

Successful rescue, medical management, rehabilitation, and translocation of a Red Panda Ailurus fulgens (Mammalia: Carnivora: Ailuridae) in Arunachal Pradesh, India - Jahan Ahmed, Sorang Tadap, Millo Tasser, Koj Rinya, Nekibuddin Ahmed \& Sunil Kyarong, Pp. 20066-20071

A rare photographic record of Eurasian Otter Lutra lutra with a note on its habitat from the Bhagirathi Basin, western Himalaya, India

- Ranjana Pal, Aashna Sharma, Vineet Kumar Dubey, Tapajit Bhattacharya, Jeyaraj Antony Johnson, Kuppusamy Sivakumar \& Sambandam Sathyakumar, Pp. 20072-20077

The first record of Medog Gliding Frog Rhacophorus translineatus Wu, 1977 (Anura: Rhacophoridae) from Chhukha District, Bhutan

- Sonam Lhendup \& Bal Krishna Koirala, Pp. 20078-20083

First record of a freshwater crab, Maydelliathelphusa masoniana (Henderson, 1893) (Decapoda: Brachyura: Gecarcinucidae) from West Bengal, India

- Ram Krishna Das, Pp. 20084-20089

Butterflies of Amrabad Tiger Reserve, Telangana, India

- Deepa Jaiswal, B. Bharath, M. Karuthapandi, Shrikant Jadhav, S. Prabakaran \& S. Rehanuma Sulthana, Pp. 20090-20097

An enumeration of the flowering plants of Kyongnosla Alpine Sanctuary in eastern Sikkim, India

- Sudhansu Sekhar Dash, Subhajit Lahiri \& Ashiho Asoshii Mao, Pp. 20098-20117

A new record of psychrotrophic Paecilomyces formosus (Eurotiales: Ascomycota) from India: morphological and molecular characterization

- Skarma Nonzom \& Geeta Sumbali, Pp. 20118-20123

Notes

Study on incidence and pathology of gastrointestinal parasitic infections in Nilgai Boselaphus tragocamelus in Hisar, Haryana, India

- Maneesh Sharma, B.L. Jangir, D. Lather, G.A. Chandratre, V. Nehra, K.K. Jakhar \& G. Narang, Pp. 20124-20127

An unusual vocalization of Brown Hawk-Owl Ninox scutulata (Raffles, 1822) (Aves:

Strigiformes: Strigidae) recorded from Kerala, India

- Riju P. Nair \& Shine Raj Tholkudiyil, Pp. 20128-20129

New distribution data on the genus Maripanthus Maddison, 2020 (Araneae: Salticidae) from southern India

- A. Asima, John T.D. Caleb, Dhruv A. Prajapati \& G. Prasad, Pp. 20130-20132

On the IUCN status of Boesenbergia albolutea and B. rubrolutea (Zingiberaceae) and typification of $B$. rubrolutea

- K. Aishwarya \& M. Sabu, Pp. 20133-20135

New records of mass seeding Cephalostachyum latifolium Munro (Poaceae) along the midelevation broadleaved forest of Sarpang district, Bhutan

- Jigme Tenzin, Sangay Nidup \& Dago Dorji, Pp. 20136-20139

Response

If habitat heterogeneity is effective for conservation of butterflies in urban landscapes of Delhi, India?' Unethical publication based on data manipulation

- Sanjay Keshari Das \& Rita Singh, Pp. 20140-20142

Publisher \& Host
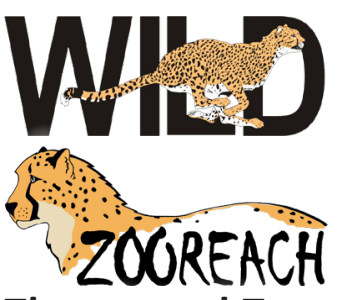

Threatened Taxa 